\title{
The Futurism Collection at the National Library of Finland in Helsinki
}

\section{Huttunen, Tomi Petteri}

de Gruyter

2019

Huttunen , T P \& Pitkäranta , T M 2019, The Futurism Collection at the National Library of

Finland in Helsinki . in G Berghaus, O S Ilnytzkyj, G E Imposti \& C Lodder (eds),

International Yearbook of Futurism Studies . vol. 9 , de Gruyter , Berlin , pp. 297-308 . https://doi.org/10.1515/97831

http://hdl.handle.net/10138/327261

https://doi.org/10.1515/9783110646238-011

unspecified

acceptedVersion

Downloaded from Helda, University of Helsinki institutional repository.

This is an electronic reprint of the original article.

This reprint may differ from the original in pagination and typographic detail.

Please cite the original version. 


\title{
The Futurism Collection at the National Library of Finland in Helsinki
}

\author{
Tomi Huttunen \& Tapio M. Pitkäranta
}

\begin{abstract}
Historically, the National Library of Finland - earlier the Helsinki University Library - was in an exceptional position regarding books from Russia. The first Finnish university was located in Turku, capital and economic centre of the Finnish province in the Kingdom of Sweden. When the country became a Grand Duchy under the suzerainty of the Russian Tsar, the university was renamed Imperial Academy of Turku. In 1828, this institution (like the capital) moved to Helsinki. Between 1707 and 1809, the Academy of Turku had the right to receive a copy of all works published in Sweden. After Finland had been ceded to the Tsar, Russian printing presses were sending legal deposit copies to the university. Furthermore, it received significant donations from Russia, especially from academic institutions in Moscow, Kazan and Saint Petersburg, as well as from private benefactors. This meant that in the nineteenth as well as early twentieth century the University Library received far more books than they were able to classify in their catalogues. Among the legal deposit copies received there were books, periodicals and other printed material in the Russian language, as well as publications written in Germanic and other Slavonic languages. Today, these legal deposit copies have been organized in eleven special collections. The collection Russica, for example, includes 19,000 titles, of which only 5,000 have been catalogued.
\end{abstract}

The Futurism collection in what was the Helsinki University Library and is now the National Library of Finland includes many rarities from the Russian avant-garde, altogether 44 titles in 49 bibliographic units. This material has been digitized, and nine books that are free of copyright are currently available online at http://www.doria.fi/handle/10024/103430.

The Futurist collection was compiled and recognized for the first time as a unified collection in 1984, while preparing a Russian avant-garde exhibition in Helsinki (see below). ${ }^{1}$ After this date, we can talk about the Helsinki Futurism collection.

Many of the Futurists were educated as artists, and the groups they joined comprised of both artists and poets. Therefore it is one of the special features of the Futurism collection that the books, typically, mix literary texts and visual images. In addition to text and illustration, the experimental nature of these artists' books is evident in the printing techniques employed. Many of them were self-made from start to finish and had a distinctly 'primitive' look to them. This is one of the reasons why these books are extremely vulnerable, rare and valuable today.

The first Futurist books were produced by Aleksei Kruchenykh at the end of 1912 by means of hectographic printing techniques: Starinnaia liubov (Old-Fashioned Love; illustrations by Mikhail Larionov), Mirskontsa (Worldbackwards; illustrations by Natalia Goncharova,

\footnotetext{
${ }^{1}$ See Bell: Venäläistä avantgardea George Costakisin kokoelmasta [Russian Avant-garde from the George Kostakis Collection].
} 
Mikhail Larionov, Nikolai Rogovin, Vladimir Tatlin) and Igra v adu (A Game in Hell; illustrations by Natalia Goncharova). These volumes represented so crude a reaction against fin-de-siècle Modernist aestheticism that contemporaries denounced them to be the creation of a lunatic.

The history of the Russian legal deposit copies after Finland gained independence in 1917 is difficult to reconstruct because of the profound changes in Russian society after the October Revolution. Information about the books received and where they came from is often fragmentary. In discussing the provenance of the books in the Helsinki Futurism collection, we can discern between different routes. In the following, we shall present four different cases that prove characteristic for their acquisition.

\section{Route no. 1: Legal deposits in the 1910s}

One of the best known and, at the same time, one of the most expensive rarities of the early Futurist years is a small almanac jointly produced by the poets Aleksei Kruchenykh and Velimir Khlebnikov, with drawings by Olga Rozanova and Nikolai Kulbin. The hectographed pages of Tè li lè were printed in Saint Petersburg by the "Svet" publishing house in 1914 and found their way into the University of Helsinki Library as a legal deposit copy. There were 50 copies printed altogether. The book has a superb front cover by Olga Rozanova, depicting a city overwhelmed by the sun. [see Fig. 1] In this way, Tè li lè participates in the Futurist discussion about the 'death of the sun', a metaphor that was the subject of the Futurist opera Pobeda nad solntsem (Victory Over the Sun, 1913). The libretto by Kruchenykh can also be found in the Helsinki Futurism collection. Kruchenykh contributed most works to the Tè li lè almanac. This was no coincidence, for he was a skilful organizer and came up with the idea of this poetic group experiment. ${ }^{2}$ Kruchenykh was educated in the fine arts and had worked as drawing teacher in Odessa. One of his best known works is a small poem printed in his own handwriting:

$\begin{array}{ll}\text { Дыр бул щыл } & \text { Dyr bul shchyl } \\ \text { убъшщур } & \text { ubishsh'ur } \\ \text { скум } & \text { skum } \\ \text { вы со бу } & \text { vi so bu } \\ \text { р л эз } & \text { r l az }\end{array}$

This poem was first published in Kruchenykh's almanac Pomada (Lipstick, 1913), ${ }^{3}$ which was a booklet made also with what the Futurists themselves called "self-writing", i.e. autographed. Kruchenykh himself wrote in a letter to Andrei Akimovich Shemshurin in 1915: "I have already met some people, who have bought Tè li lè and did not understand a word of dyr bul schyl, but were astonished by its visual artistic quality". ${ }^{4}$

In several auto-commentaries on the above text, Kruchenykh has pointed out that the poem is essentially Russian and both trans-sensible and trans-rational. In a declaration related to the poem he wrote: "As a matter of fact, in this five-line poem there is more of the Russian

\footnotetext{
${ }^{2}$ Kovtun: Russkaia futuristicheskaia kniga, p. 6.

${ }^{3}$ Both versions of the poem have been reproduced in International Yearbook of Futurism Studies 6 (2016), p. 261.

${ }^{4}$ Kruchenykh: "Mir zatreshchit, a golova moia uzhe izriadno...", p. 30. See also: Levinton: Stat'i o poezii russkogo avangarda, p. 12.
} 
national spirit than in all of Pushkin". ${ }^{5}$ Of course, the name of Pushkin is no coincidence here, as he was one of the Russian writers to be thrown overboard from the steamship of contemporary literature, according to the Futurist manifesto Poshchechina obshchestvennomu $v k u s u$ (A Slap in the Face of Public Taste, 1912). ${ }^{6}$ This manifesto is contained in an eponymous book that can also be found in the Helsinki Futurism collection. David Burliuk had asked Kruchenykh to write a poem made of "unknown words", and Kruchenykh responded with Dyr bul shchyl. Combatting against the culture of the past was an important trait in Russian Futurism and formed the central idea behind the manifesto A Slap in the Face of Public Taste, which gave resounding slaps in the faces of nineteenth-century Realists, fin de-siècle Symbolists and some contemporary Futurists, too. Russian Futurism comprised discordant groups of poets, each competing with the others and trying to surpass each other in terms of experimentation, non-conformism, madness and courage. The avant-garde poets tried to be unique and to gain a reputation of being the first and the best of their time.

Continuing the above-mentioned discourse on the 'death of the sun', one can point towards another poetry anthology in the Helsinki collection, Konstantin Bolshakov's Solntse na izlete (The Last Trajectory of the Sun), published in 1916 by the Centrifuge group. In the early 1920s, many more competing circles of experimental poets emerged, sometimes consisting only of two or three members. The New Economic Policy (NEP) of the 1920s made it possible for such groups to engage in small-scale entrepreneurship and to publish an endless array of manifestos and anthologies. In March 1922, Moscow alone boasted 143 publishing houses. Never again has Russia enjoyed the presence of so many literary groups.

\section{Route no. 2: Books bought by Andrei Igelström}

The first official librarian of the Russian collection at the Helsinki University Library was Andrei Igelström. He was appointed in 1902 and stayed in his position until 1927. Igelström was born in 1860 into a Baltic Swedish family from Vilnius. During his first career he was a military officer, but he left the army in 1900 to focus on academic studies. He taught Russian at the University of Helsinki, wrote about Russian literature in Finnish journals and about Finland in Russian publications. He also published, together with the professor of Russian languages and literature Josef Mandelshtam, a Swedish-Russian dictionary.

After the October Revolution, the right for legal deposits from Russia was annulled. From now on, the library had to either buy or trade for all the books it needed. Official ties between the library and the new Soviet institutions had to be established all over again. Igelström's personal relationships were crucial for this task. In 1925, he wrote a memorandum about the current state of book acquisition from Russia:

To fulfil the needs of the library for out-of-print books, relations have been established with the best antiquarian bookstore in Saint Petersburg, "Excursant". There I have bought some sold-out books printed after 1917, as well as several older works that were missing in the library and which, for many years, we have been searching for. ${ }^{7}$

\footnotetext{
${ }^{5}$ Brodskii and Sidorov: Literaturnye manifesty: Ot simvolizma do "Oktiabria", p. 173. [А. Крученых, В. Хлебников. Слово как таковое. М., 1913, с. 9.; Kruchenykh, Alexei, and Velimir Khlebnikov: "From The Word as Such." Anna Lawton, and Herbert Eagle, eds.: Russian Futurism Through its Manifestoes, 1912-1928. Ithaca/NY: Cornell University Press, 1988. 60]

6 "Throw Pushkin, Dostoevsky, Tolstoy, etc., etc. overboard from the Ship of Modernity." "A Slap in the Face of Public Taste." Anna Lawton, and Herbert Eagle, eds.: Russian Futurism Through Its Manifestoes, 1912 1928. Ithaca/NY: Cornell University Press, 1988. 51.]

${ }^{7}$ Igelström: Promemoria. Helsinki University Library archives. HYK:Hi10.1
} 
It was thus from this bookstore that $V$. $V$. Kandinskii: Tekst khudozhnika (W. Kandinsky: The Artist's Text, 1918) was bought for the Futurism collection at a price of 1,50 rubles in 1926.

The antiquarian bookshop "Excursant" operated from 1922 to 1930 on Liteyny Prospekt 47 and was the biggest in the city. The company was said to buy entire libraries and could therefore offer the best selection, but as it priced rare books aggressively high it gained the reputation of acting like "sharks". ${ }^{8}$ The New Economic Policy made this kind of private enterprise possible, but private bookshops were soon replaced by State-owned shops. The most important of these was "Mezhdunarodnaia kniga" (International Book), founded in 1923. It had a monopoly on book imports and exports, but this could not prevent individuals such as Igelström from travelling to Russia and buying individual books from shops such as "Excursant".

At first, "Mezhdunarodaia kniga" was not as prominent or successful as the private business, but it had branches both in Leningrad and in Moscow, and its antiquarian department employed experienced booksellers such as Pavel Petrovich Shibanov and Fedor Grigorevich Shilov, who had made their name in pre-Revolutionary Russia. The company sold valuable antiquarian items to foreign clients in order to help funding of the industrialization process that had been announced in the first five-year plan. Their biggest competitive advantage was the access to the millions of books seized by the authorities from private libraries. ${ }^{9}$

On 17 April 1929, the Helsinki library acquired from "Mezhdunarodnaia kniga" through the Finnish embassy in Moscow, two books now in the Futurism collection: Sdvigologiia russkogo stikha (Shiftology of Russian Poetry, 1922) and Apokalipsis v russkoi literature (Apocalypse in Russian Literature, 1923) by Aleksei Kruchenykh. By the end of the 1920s, the library stopped buying books from "Excursant", possibly because its prices or selection were no longer attractive. What distinguishes the acquisition of Kandinsky's and Kruchenykh's books from the Futurist books that arrived automatically as legal deposit copies, is that they were purchased due to a conscious decisions of a librarian who had recognized their value. The library already held books by Kruchenykh, and they had read about his new works in Knizhnaia letopis' (the annual catalogue of books published in Russia) and decided to purchase them. A letter in the library archive from 1933 offers evidence that Finns were reading Kruchenykh's books shortly after their acquisition. The document shows that Jalo Kalima, the director of the Russian Department at the time, was concerned about an Eastern orthodox priest who had borrowed Sdvigologiia russkogo stikha and had not returned it on time.

\section{Route no. 3: The Father of Russian Futurism}

The poet and artist David Davidovich Burliuk was one of the founding figures of Russian Futurism. On the covers of his books, he often called himself the "Father of Russian Futurism". The National Library of Finland has in its collections fifteen books from the 1920s and 1930s that were donated to the library by Burliuk himself.

Burliuk fled with his family the harsh conditions of post-Revolutionary Russia. Travelling with his family through Siberia, he arrived in Vladivostok in June 1919, and from 1920 to

\footnotetext{
${ }^{8}$ Berkov: Istoriia sovetskogo bibliofil'stva, pp. 88-89.

${ }^{9}$ Afanasev: "The Export of Books from the USSR from 1918 to the 1930s."
} 
1922 he spent time in Japan before finally arriving in the United States, where he gained citizenship in 1930. Burliuk continued his literary and artistic endeavours also in America. In New York, together with his wife, Mariia Nikiforovna Burliuk, he founded a publishing house mainly concerned with publishing his own works.

According to the library acquisition catalogue, the fifteen books arrived in the Slavonic library as a "gift from the author". The library archive holds a letter from Valery SemenovTyan-Shansky, ${ }^{10}$ a member of the organizing committee of an exhibition of Russian books, Russkaia kniga za rubezhom (Russian Book Abroad), in which he lists the books that should be donated to the library. The date of acquisition is 25 September 1933, only a day after the exhibition, held in the clubhouse of the Russian colony in Finland, closed in Helsinki. Semenov-Tyan-Shansky wrote an article about the exhibition in Zhurnal sodruzhestva, the only Russian language periodical published in Finland at the time. In his view, the almost 1,000 exhibits signalled how widespread and varied the émigré publishing business was in Finland, and he regretted that only 130 of the books on show were actually sold. ${ }^{11}$

Most of the works Burliuk donated to the library had been written by himself, but there were also two small anthologies by Vladimir Mayakovsky, one book each by Erikh Gollerbakh on the poetry and art of David Burliuk, and three collections by the collectives Kitovras (Centaur) and American LEF. ${ }^{12}$ The only book out of the fifteen that were donated to the Futurism collection is David Burliuk and His Art (1932). It is a bound volume containing several previously published pamphlets and includes Literaturnii trud Davida D. Burliuka (Literary Work of David D. Burliuk, 1931) by Igor Postupalsky, Entelekhizm: Iskusstvo kak organicheskii protsess (Entelechy: Art as an Organic Process, 1929) by Burliuk himself, Gileia (Hylaea, 1931) by Benedikt Livshits, Krasnaia strela (Red Arrow, 1932), an anthology of Soviet poets, and Oshima (1927) by Burliuk. It is difficult to say how exactly the selection for the Helsinki Futurism collection was made. It appears to have been a selfpromotion exercise by Burliuk, and there is only one copy of the 1932 volume in the State Library in Moscow, but none in any other regional library of Russia.

\section{Route no. 4: The Innovative Director}

As we have seen, the Helsinki Futurism collection contains volumes of a highly unique character that found their way into the Slavonic collection by different routes. The Futurism collection itself was not recognized as a unity and catalogued as such until the 1980s, when twenty of its items were included in the exhibition of George Kostakis' famous collection of Russian avant-garde art in the Helsinki City Art Museum. These books included the Futurist anthologies Sadok Sudei (A Trap for Judges, 1910 and 1912), Futuristy: Pervyi zhurnal russkikh futuristov (Futurists: First Journal of the Russian Futurists, 1914), Goncharova's Misticheskie obrazy voiny (The Mystical Images of the War, 1914), other graphic albums by Natalia Goncharova and Mikhail Larionov, as well as many of the above-mentioned publications.

\footnotetext{
${ }^{10}$ Valerii Semenov-Tian'-Shanskii (1871-1968), a Russian émigré painter and former civil servant, published articles in Zhurnal sodruzhestva in Vyborg and Vozrozhdenie in Paris. See Bekzhanova: "A prishlos'v razluke zhit' goda...", p. 467.

${ }^{11}$ Semenov-Tian'-Shanskii: "Russkaia kniga za rubezhom”, pp. 24-26. Also see Timofeev: Redaktsionnaia perepiska "Zhurnala sodruzhestva", p. 154.

12 The journal Kitovras (three issues only) was published by Bazar Press from August to October 1924. It was named after Vassily Kamensky's publishing enterprise of the same name in Moscow. American Lef emerged in 1924 from a publishing firm in New York called "Hammer and Sickle".
} 
Among the exhibited books, several cannot be traced back to routes described above. They arrived in the collection surprisingly late and were purchased by Jarmo Suonsyrjä, who worked in the Slavonic library from 1967 to 2003. He entertained close contacts with Russian libraries and academic institutions, but also knew places in Soviet Leningrad where he could acquire books from local poets, artists or dealers. In the early 1990s, when almost everything was for sale in post-Soviet Russia, he used the opportunity to expand the Futurism collection in Helsinki with rarities such as Aleksandr Kusikov's Poema poem (The Poem of the Poems), an Imaginist erotic work from 1920. Even though the scholarly interest in Russian Imaginism (c.1918 - 1928) has noticeably increased during the last decades, Kusikov is not well known, not even to specialists. This is likely to change, because Kusikov's avant-garde way of combining the Islamic tradition with Christian elements - especially in the poem Koevangelieran (Ko-gospel-ran, 1920) - proves to be of great interest in today's world. This volume is only one of many examples that demonstrates that the Helsinki Futurism collection offers many potential to study groups and academic researchers.

\section{Bibliography}

\section{The Helsinki Futurism Collection}

Aksenov, Ivan: Neuvazhitel'niia osnovaniia [With illustrations by A. Ekster]. Moskva: Tsentrifuga, 1916.

Blok, Aleksandr: Dvenadtsat': Skify [With illustrations by N. Goncharova and M. Larionov]. Parizh: Mishen', 1920.

Bol'shakov, Konstantin: Solntse na izlete: Vtoraia kniga stikhov, 1913-1916. Moskva: Tsentrifuga, 1916.

Burliuk, David et al.: David Burliuk and His Art. New York: Izd-vo Marii N. Burliuk, 1932.

Burliuk, David et al.: Zatychka: Sbornik, risunki, stikhi [With illustrations by V. Burliuk]. Moskva: Futuristy Gileia, 1913.

Charekova, Nina: Zelenyi Kutais: Stikhi. Kutais: Tip. Kut. otd. O-va rasprostr. gramotn. sredi gruzin, 1916.

Churilin, Tihon: Vesna posle smerti: Stikhi [With illustrations by Natalia Goncharova]. Moskva: Al'ciona, 1915.

Dokhlaia luna: Stikhi, proza, stat'i, risunki, oforty [With illustrations by D. Burliuk and V. Burliuk]. Moskva: Pervyi zhurnal russkikh futuristov, 1913.

Dokhlaia luna: Stikhi, proza, stat'i, risunki, oforty [With illustrations by D. Burliuk and V. Burliuk]. 2nd edn Moskva: Pervyi zhurnal russkikh futuristov, 1914.

Eganbiuri, Eli [Zhadevich, Il'ia]: Nataliia Goncharova, Mikhail Larionov. Moskva: Ts. A. Miunster, 1913. Filonov, Pavel: Propeven' o prorosli mirovoi. Petrograd: Mirovyi raztsvet, 1915.

Futuristy: Pervyi zhurnal russkikh futuristov № 1-2 [With illustrations by D. Burliuk, V. Burliuk and A. Ekster]. Ed. by V. Kamenskii. Moskva: Izdatel’ David Burliuk, 1914.

Goncharova, Nataliia: Misticheskie obrazy voiny: 14 litografii. Moskva: V. N. Kashin, 1914.

Grigor'ev, Boris: Raseia. Peterburg: V. M. Iasnyi, 1918.

Guro, Elena: Nebesnye verbliuzhata: Stikhi i proza. Sankt-Peterburg: Zhuravl', 1914

Guro, Elena: Sharmanka: Piesy, stikhi, proza. Sankt-Peterburg: Tipografia Sirius, 1909.

Kandinskii, Vasilii: V. V. Kandinskii: Tekst khudozhnika: 25 reproduktsii s kartin 1902-1917 gg., 4 vin'etki. Moskva: Otdel izobrazitel'nykh iskusstv Narodnogo kommissariata po prosvescheniiu, 1918.

Kruchenykh, Aleksei: Apokalipsis v russkoi literature [With illustrations by N. Nagorskaia]. Moskva: Tipografiia TsIT, 1923.

Kruchenykh, Aleksei: Chort i rechetvortsy. Sankt-Peterburg: Tipo-lit. t-va Svet, 1913.

Kruchenykh, Aleksei: Faktura slova: Deklaratsiia. Moskva: Skoropechatnia TsIT, 1923.

Kruchenykh, Aleksei: Fonetika teatra. Moskva: Izd-vo Vserossiiskogo soiuza poetov, 1925.

Kruchenykh, Aleksei: Golodniak. Moskva: Tipografiia TsIT, 1922.

Kruchenykh, Aleksei: Liki Esenina ot kheruvima do khuligana: Esenin v zhizni i portretakh [With illustrations by V. Kulagina]. Moskva, 1926.

Kruchenykh, Aleksei: Pobeda nad solntsem. Sankt-Peterburg: Tipografiia t-va Svet, 1913.

Kruchenykh, Aleksei: Sdvigologiia russkogo stikha: Trakhtat obizhal'nyi [With illustrations by I. Kliun]. Moskva: Tip. TsIT, 1922. 
Kruchenykh, Aleksei: Voina [With illustrations by O. Rozanova]. Sankt-Peterburg: Tipografiia t-va gazety Svet, 1916.

Kruchenykh, Aleksei: Vselenskaia voina: Tsvetnaia klei. Petrograd: Tipografiia t-va Svet, 1916.

Kruchenykh, Aleksei: Zhivoi Maiakovskii: Razgovory Maiakovskogo: Zapisal i sobral A. Kruchenykh. Moskva: Gruppa druzei Maiakovskogo, 1930.

Kruchenykh, Aleksei: Zudesnik: Zudutnye zudesa. Moskva: Skoropechatnia TsIT, 1922.

Kruchenykh, Aleksei, and Velimir Khlebnikov: Tè li lè [With illustrations by O. Rozanova]. Sankt-Peterburg: Tipo-litografiia t-va Svet, 1914.

Kusikov, Aleksandr Borisovich: Poema poem [With illustrations by B. Erdman]. 2nd edn Moskva: Imazhinisty, 1920.

Lef agitki Maiakovskogo, Aseeva, Tret'iakova [Cover by V. Kulagina-Klucis]. Moskva: Izdanie Vserossiiskogo soiuza poetov, 1925.

Liubov k trem apel'sinam: Zhurnal doktora Dapertutto. Ed. by V. Meierkhol'd. 2-7 (1914), 1-7 (1915), 1-3 (1916). Petrograd. [s.n.].

Moloko kobylits: Sbornik: Risunki, stikhi, proza [With illustrations by D. Burliuk and V. Burliuk,]. Moskva: Lit. $\mathrm{K}^{\circ}$ futuristov Gileia, 1914.

Moskovskie mastera: Zhurnal iskusstv. Moskva: Tip. T-va A. A. Levenson, 1916.

Neo-futurizm: Vyzov obschestvennym vkusam. Sbornik. [With illustrations by N. Grigor'ev, N. Dankov and I. Orlov]. Kazan': Futurum, 1913.

Oslinyi khvost i mishen': Sbornik statei i risunkov. Moskva: Tipo-lit. V. Rikhter, 1913.

Poschechina obschestvennomu vkusu: Stikhi, proza, stat'i. Sbornik. Moskva: G. L. Kuz'min, 1913.

Sadok sudei: Sbornik [With illustrations by V. Burliuk]. Sankt-Peterburg: Zhuravl', 1910.

Sadok sudei II: Sbornik [With illustrations by D. Burliuk, V. Burliuk, E. Guro, N. Goncharova and M. Larionov]. Sankt-Peterburg: Zhuravl', 1913.

Soiuz molodezhi II: Obschestvo khudozhnikov [With illustrations by P. Filonov, I. Shkol'nik, E. Spandikov, Ts. Shleifer and O. Rozanova]. Peterburg, 1912

Soiuz molodezhi III: Pri uchastii poetov Gileia [With illustrations by I. Shkol'nik and O. Rozanova]. Peterburg, 1913.

Strelets: Sbornik no. 1. Ed. by Aleksandr Belenson [With illustrations by V. Burliuk, N. Kul'bin and O. Rozanova]. Petrograd: Strelets, 1915.

Strelets: Sbornik no. 2. Ed. by Aleksandr Belenson [With illustrations by N. Kul'bin]. Petrograd: Strelets, 1916.

Strelets: Sbornik no. 3. Ed. by Aleksandr Belenson [With illustrations by M. D. Burliuk and Iu. Annenkov]. Petrograd: Strelets, 1922.

Trebnik troikh: Sbornik stikhov i risunkov [With illustrations by D. Burliuk, V. Maiakovskii and V. Tatlin]. Moskva: G. L. Kuz'min i S. D. Dolinskii, 1913.

Vesennee kontragentstvo muz. Ed. by David Burliuk \& Samuil Vermel' [With illustrations by D. Burliuk, V Burliuk and A. Lentulov]. Moskva: Studiia Burliuka i Vermel', 1915.

\section{Archival sources}

Igelström, Andrei: Promemoria. Helsinki University Library archives. HYK:Hi10.1

\section{Critical Literature}

Afanas'ev, Mikhail D.: "The Export of Books from the USSR from 1918 to the 1930s." Solanus NS 15 (2001): 51-67.

Baschmakoff, Natalia, and Marja Leinonen: Russian Life in Finland 1917-1939: A Local and Oral History. Helsinki: Institute for Russian and East European Studies, 2001.

Bekzhanova, Nailia Vilevna, et al.: "A prishlos'v razluke zhit' goda...": Rossiiskoe zarubezhe v Finliandii mezhdu dvumia voinami: Materialy k biobibliografii 1987-2002 ["And we had to live apart for a year ...": The Russian Diaspora in Finland between the Two Wars: Materials for a Bio-bibliography, 1987-2002]. Sankt-Peterburg: Sudarynia, 2003.

Bell, Marja-Liisa, et al., eds.: Venäläistä avantgardea George Costakisin kokoelmasta = Ryskt avantgarde ur George Costakis samling. Helsinki: Helsingin kaupungin taidemuseo / Helsingfors stads konstmuseum, 15.6. -30.9. 1984. 
Berkov, Pavel Naumovich: Istoriia sovetskogo bibliofil'stva [History of Soviet Bibliophilia]. Moskva: Kbiga, 1971.

Brodskii, Nikolai L., and Nikolai P. Sidorov, eds.: Literaturnye manifesty: Ot simvolizma do "Oktiabria" [Literary Manifestos: From Symbolism to the October Revolution]. Moskva: Agraf, 2001.

Kruchenykh, Alexey: "Mir zatreshchit, a golova moia uzhe izriadno...": Pis'ma A.A. Shemshurinu i M.V. Matiushinu, 1913-1921. Predislovie, podgotovka teksta, primechaniia i kommentarii Andreia Krusanova. Moskva: Gileia, 2012.

Levinton, Georgii: Stat'i o poezii russkogo avangarda [Essays on Russian Avant-garde Poetry]. Helsinki: University of Helsinki Press, 2017.

Semenov-Tian'-Shanskii, Andrei Petrovich: "Russkaia kniga za rubezhom.” [The Russian Book Abroad] Zhurnal sodruzhestva [Commonwealth Journal] 10 (1933): 24-26

Timofeev, Aleksandr Genrikhovich: Redaktsionnai perepiska "Zhurnala sodruzhestva" za 1932-1936 gody: S prilozheniem polnoi rospisi soderzhaniia zhurnala. Iz istorii russkoi emigratsii v nezavisimoi Finlandii [The Editorial Correspondence of the Commonwealth Journal for the Years 1932-1936: With a Complete List of the Contents of the Journal. On the History of Russian Emigration into Independent Finland]. SanktPeterburg: Mir, 2010. 